\title{
Analysis of Consumer Misconception in Cosmeceutical Advertisements
}

In Seon Shim, Kyungja Kim

Department of Consumer Studies, The Catholic University of Korea, Bucheon-si, Gyeonggi-do, Korea

\author{
*Corresponding author: Kyungja Kim, \\ Department of Consumer Studies, The \\ Catholic University of Korea, 43, Jibong-ro, \\ Bucheon-si, Gyeonggi-do 14662, Korea \\ Tel.: +82 21644304 \\ Email:kimkj@catholic.ac.kr
}

Received April 18, 2020

Revised May 25, 2020

Accepted May 29, 2020

Published June 30, 2020

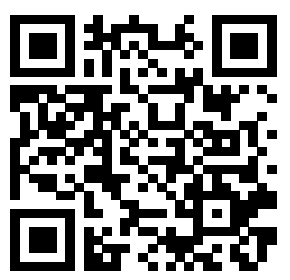

\begin{abstract}
Purpose: This study analyzed consumer misconception in cosmeceutical advertisements as revealed by the Korean Food and Drug Administration (KFDA). After examining 141 advertisements violating the regulation of unjust indication and advertisement in cosmetics, the key factors and management plan of consumer misconception were discussed. Methods: Data was sampled from advertisements that had been penalized by the Korean Ministry of Food and Drugs Safety for unfair advertising. Each case was interpreted against the regulation of unjust indication and advertisement in cosmetics. Results: Skincare products claimed the highest percentage (78.9\%) among other cosmeutical products violating regulations for overstating their effects of care, renewal, antiaging property, reinforcement of immunity, etc. Cosmetic effects of special ingredients were exaggerated by text and imagery that lead to consumer misconception. Conclusion: The distinction between medical and cosmeceutical products and judgment for violations is equivocal. To decrease consumer misconception, the KFDA should make the regulation clause concrete and educate people involved in regularization.
\end{abstract}

Keywords: Cosmeceutical, Cosmeceutical advertisement, Consumers' misconception, Cosmeceutical law, Consumer deceit

\section{Introduction}

한국보건산업진흥원(KHIDI, 2017)에 따르면 한국 화장품 시장 은 2012년 이래 연평균 $16 \%$ 씩 성장해왔다. 이는 동기간 경제성 장률 $3 \%$ 에 비하면 괄목할만한 수치이다. 2016년 화장품제조판매 업체수는 8,175 개사로 2013 년 3,884 개사에 비해 3 년만에 2 배 이 상 증가하였다. 다품종 소량생산이 가능하고 original equipment manufacturing (OEM)과 original development manufacturing $(\mathrm{ODM})$ 이 가능한 산업특성상 중소기업의 진입이 용이하기 때문에 화장품 시장의 성장은 앞으로도 지속될 것으로 예상된다. 아울러 기 능성 화장품 시장도 빠르게 증가하고 있다. 미세먼지 증가와 일교 차 증가 등 환경 악화와 미용시술의 증가로 피부가 민감해지면서 기 능성 화장품 시장도 계속 성장할 것으로 전망된다. 우리나라 화장품 판매업체의 전체 매출 중 기능성화장품의 매출은 약 $25 \%$ 를 차지하 고, 판매업체 $87 \%$ 가 기능성화장품을 취급하고 있는 것으로 나타난 다(You \& Kwon, 2016).
식약처 정의에 따르면 '기능성화장품'이란 화장품 중에서 피부의 미백이나 주름개선에 도움을 주거나, 자외선으로부터 보호해주는 제품, 모발의 색상 변화·제거 또는 영양공급에 도움을 주는 제품, 피 부나 모발의 기능 약화로 인한 건조함, 갈라짐, 빠짐, 각질화 등을 방지하거나 개선하는 데에 도움을 주는 제품의 어느 하나에 해당되 는 것으로서 총리령으로 정하는 화장품을 말한다. 기능성화장품은 코스메슈티컬 또는 더마코스메틱이라고도 불리며 치료를 주목적으 로 하는 의약품과 달리 효과는 낮지만 안전성은 높은, 의약품과 일 반화장품 사이의 제품에 해당하는 것으로 구분하고 있다(KSURE, 2018). 기능성 화장품은 그 정의상 소비자가 의약품과 같은 기능을 하는 것으로 오인할 소지가 크기 때문에 식품의약품안전처는 의약 품으로 오인하게 만드는 화장품 표시 및 광고에 대해 감시하고 규제 를 하고 있다.

기능성화장품에 대한 연구들은 대부분 화장품에 대한 소비자 인 식과 만족도를 조사하거나 화장품 구매행동을 파악하여 마케팅 전 략을 얻고자 하는 것이 대부분이다. 우선 기능성 화장품 구매경험을 
보면 조사대상자 중 적게는 $45.5 \%$ 에서 $89.8 \%$ 가 구매경험이 있을 정도로 구매경험은 많은 편이다(Kim \& Han, 2018; Park \& Kwon 2017; Park et al., 2014). 기능성화장품에 대한 인지도도 비슷한 수준이나 성별에 따른 차이가 있다. $\operatorname{Kim} \& \operatorname{Han}$ (2018)의 연구에서 는 여성소비자인 조사 대상자의 $61.1 \%$ 가 메디컬 화장품에 대해 들 어본 적이 있다고 답하였고 You \& Kwon (2016)의 연구에서는 여성 응답자의 $2 / 3$ 정도가 일반화장품과 기능성화장품의 차이를 알고 있 다고 한 반면 남성 응답자들은 $2 / 3$ 가 그 차이를 모른다고 응답하였 다. 또한 여성 소비자들도 기능성화장품 구매시 미백, 주름개선, 자 외선 차단 등과 같은 효능을 고려한다고 응답하였으나 정작 효능을 가져오는 성분에 대해 잘 모르고 있다고 답하였다.

기능성화장품에 대한 소비자만족도도 연구마다 다양하게 나타난 다. Park \& Kwon (2017)의 연구에서는 기능성 화장품의 일종인 코 스메슈티컬을 경험한 소비자들 중 $94 \%$ 가 재구매의향을 가지고 있을 정도로 만족도가 높았고 Jang et al. (2012)의 연구에서도 일반화장 품에 비해 기능성화장품에 대한 소비자 만족도가 대체로 높았다. 그 러나 Choi \& Hong (2005)의 연구에서는 응답자의 절반에 못 미치 는 $47.1 \%$ 가 기능성 화장품에 대해 매우 만족 또는 대체로 만족하는 정도였다. 또한 Park et al. (2014)의 연구와 Yun \& Kweon (2004) 의 연구에서는 소비자 만족도 점수가 5 점 만점에 3 점을 약간 넘는 수준에 불과하여 기능성화장품에 대한 소비자 만족도가 높다고 보 기는 어렵다. 응답자들이 만족하지 못하는 이유는 화장품의 효과를 크게 느끼지 못했거나 기능에 대한 확신이 없어서, 또는 부작용을 겪어서인 것으로 나타나고 있다. Yun \& Kweon (2004)의 연구에서 는 기능성 화장품 사용자의 $64.4 \%$ 가 피부홍조나 가려움, 피부 트러 블 등의 부작용을 경험한 것으로 나타났다.

기능성화장품 매출 촉진을 위한 연구들(Shim \& Kim, 2008; Meng \& Pan, 2012; Phaiboon-Udomkarn \& Josiassen, 2014)은 정교한 방법론을 적용해 소비자를 설득하는 방법을 찾아내는 데 초 점을 맞추고 있다. Phaiboon-Udomkarn \& Josiassen (2014)은 기 능성화장품에 대한 소비자의 위험지각을 낮추는 다양한 방법을 탐 구하고 의료인 등 전문가의 이미지를 빌려오거나 판매원의 전문성 을 높이는 방법 등이 효율적이라는 것을 제안하였다. Sim \& Kim (2008)과 Kim \& Han (2018)은 소비자의 코스메슈티컬 구매의도를 높이기 위해 브랜드 신뢰도와 판매원 이미지를 제고하는 것이 가장 필요하다는 결론을 내렸다. Meng \& Pan (2012)의 연구에서는 소 비자가 기능성화장품 광고에서 제품의 효과와 유용성을 지각하도록 만드는 것이 중요함을 발견하였다.

기능성화장품의 매출촉진을 위한 연구에 비해 기능성화장품의 표 시나 광고 문제를 분석한 연구는 거의 없는 실정이다. 기능성화장품 은 속성상 의약품과 일반화장품의 중간에 위치하여 성분이나 효능 을 과장하여 의약품의 기능을 하는 것처럼 소비자를 오도해 논란이 많은 분야임에도 불구하고 이 분야에 대한 연구는 매우 드물다. 미 국에서 행해진 Turnbull (2016)의 연구 외에 국내에서는 Lee (2002)
와 Song \& $\operatorname{Kim}$ (2014)의 연구가 있을 뿐이다. Turnbull (2016) 은 미국 화장품 시장의 규제관련 담당자들과 화장품 사업자들을 대상으로 미국의 기능성화장품 규제제도에 대한 인식을 조사하였 다. 응답자들은 자율적 화장품 등록 프로그램(Voluntary Cosmetic Registration Program, VCRP)을 통하여 규제기관인 FDA에 제품 을 등록하는데 매출증진과 경쟁력 확보를 우선시하다 보니 과도한 표현을 하게 된다고 하였다. 응답자의 $2 / 3$ 정도는 $85 \%$ 가 홍조 감소 경험, 깊은 주름 유의하게 감소, 2 주 안에 눈썹이 자라남, 유전자 활 동 강화, 성장 단백질 생성과 같은 표현이 문제가 될 수 있다는데 동 의하였다. 또한 응답자들은 코슈메슈티컬의 확장에 따라 화장품과 의약품을 다시 정의하고 코슈메슈티컬에 대한 독립적인 표시·광고 규정을 만드는 것이 필요하다고 지적하였다.

Lee (2002)는 시장규모에 따라 상위 29종의 기능성 화장품을 선 정한 후 일간지와 여성잡지에 실린 광고를 분석한 후 지나친 과장과 모호한 표시를 통해 의약품으로 오인하게 하는 광고가 일반화된 현 상이라고 하였다. 임상테스트 내용이나 보증내용이 모호한 것은 물 론, 구체적 설명이 없는 자연산 성분 또는 천연성분이라는 표현, 부 수적인 극소량의 성분을 주성분으로 표현하는 것이 대표적인 모호 한 표시의 사례이다. 이 외에도 심신기능 강화, 피부노화의 원인 유 해산소 제거, 호르몬 분비 촉진, 세포재생 및 세포증진, 피부치료 전 문, 신진대사와 혈액순환 촉진 등 의약품으로 오인하게 할 수 있는 표현들이 다수 사용되고 있는 것으로 나타났다.

일반 화장품과 달리 기능성화장품은 의료적 효능이 있기 때문에 소비자들이 이를 의약품으로 오인하는 경우가 발생할 수 있다. 의료 적 효과는 긍정적인 측면도 있지만 잘못 사용할 경우 부작용이 발생 할 수 있음을 의미한다. 또한 의료효과를 기대하며 기능성화장품에 과도한 의료효과를 기대하다가 적절한 치료시기를 놓쳐 상황이 악 화되는 사례도 발생할 수 있다. Song \& Kim (2009)은 우리나라 코 슈메슈티컬 시장 현황을 진단하면서 기능성 화장품을 성형을 대체 할 수 있는 정도의 효능을 갖는 것으로 과장하는 표시, 광고의 문제 점을 지적하고 공식적 인증과 임상데이터가 없는 광고에 대한 규제 가 필요함을 역설하였다. Lee (2018)도 소비자들의 안티 폴루션 화 장품에 대한 인식을 조사한 후 소비자 만족을 위해서는 과학적 근거 자료에 기반한 표시·광고 전략이 필요하다고 주장하였다.

현재 우리나라에서 화장품 표시와 광고에 대한 규제는 화장품법 에 따라 식품의약품안전처에서 주관하고 있다. 식약처는 다음과 같 은 경우 화장품 표시와 광고에 대해 심사한다. 첫째는 화장품이 각 종 질병 치료에 효능·효과가 있는 것처럼 광고하거나 거짓 체험기를 이용해 광고하는 경우, 허가받은 내용과 다르게 광고·판매 하는 행 위가 발생하고 이에 대한 신고가 접수된 경우이다. 두 번째는 특정 성분이나 효능에 대한 과장이나 허위가 사회적 이슈가 될 정도로 커 진 경우이다. 이러한 상황은 식약처가 직접 판단해 점검하고 그 결 과를 온라인 불법 유통 신고 게시판을 통해 발표한다.

화장품 표시 및 광고에 대한 심사기준은 부당한 표시 광고 행 
위 등의 금지에 관한 화장품법 13 조에 나와 있는데 그 내용은 1) 의 약품으로 잘못 인식할 우려가 있는 표시 또는 광고 2) 기능성화장품 이 아닌 화장품을 기능성화장품으로 잘못 인식할 우려가 있거나 기 능성화장품의 안전성 - 유효성에 관한 심사결과와 다른 내용의 표 시 또는 광고 3) 천연화장품 또는 유기농화장품이 아닌 화장품을 천 연화장품 또는 유기농 화장품으로 잘못 인식할 우려가 있는 표시 또 는 광고 4) 그 밖에 사실과 다르게 소비자를 속이거나 소비자가 잘 못 인식하도록 할 우려가 있는 표시 또는 광고 의 4 가지 이다. 심사 기준이 객관적으로 애매할 수밖에 없는 '소비자가 잘못 인식할 가능 성'으로 표기되어 있는데 이를 좀 더 명확히 하고자 화장품법 13 조 에 대한 시행세칙 제 22 조 2 항에서 화장품 표시·광고시 준수사항에 서 금지하는 광고에 대한 내용을 다음과 같이 11 개로 세부적으로 제 시하고 있다.

\section{2. 화장품 표시·광고 시 준수사항}

가. 의약품으로 잘못 인식할 우려가 있는 내용, 제품의 명칭 및 효 능·효과 등에 대한 표시·광고

나. 기능성화장품, 천연화장품 또는 유기농 화장품이 아님에도 불 구하고 제품의 명칭, 제조방법, 효능·효과 등에 관하여 기능성화장 품, 천연화장품 또는 유기농 화장품으로 잘못 인식할 우려가 있는 표시·광고

다. 의사·치과의사·한의사·약사·의료기관·연구기관 또는 그 밖의 자(할랄 화장품, 천연화장품 또는 유기농 화장품 등을 인증·보증하 는 기관으로서 식품의약품안전처장이 정하는 기관은 제외)가 이를 지정·공인·추천·지도·연구·개발 또는 사용하고 있다는 내용이나 이 를 암시하는 등의 표시·광고 (다만, 법 제2조 제1호부터 제3호까지 의 정의에 부합되는 인체 적용시험 결과가 관련 학회발표 등을 통 하여 공인된 경우에는 그 범위에서 관련 문헌을 인용할 수 있으며, 이 경우 인용한 문헌의 본래 뜻을 정확히 전달하여야 하고, 연구자 성명·문헌명과 발표 연월일을 분명히 밝혀야 함)

라. 외국제품을 국내제품으로 또는 국내제품을 외국제품으로 잘못 인식할 우려가 있는 표시·광고

마. 외국과의 기술제휴를 하지 않고 외국과의 기술제휴 등을 표현 하는 표시·광고

바. 비교 대상 및 기준을 분명히 밝히고 객관적으로 확인될 수 있는 사항만을 비교하여 제시하는 표시·광고(배타성을 띤 "최고" 또는 " 최상" 등의 절대적 표현의 표시·광고는 금지)

사. 사실과 다르거나 부분적으로 사실이라고 하더라도 전체적으로 소비자가 잘못 인식할 우려가 있는 표시·광고 또는 소비자를 속이 거나 소비자가 속을 우려가 있는 표시·광고

아. 품질·효능 등에 관하여 객관적으로 확인될 수 없거나 확인되지 않은 광고. 화장품의 범위를 벗어나는 표시·광고

자. 저속하거나 혐오감을 주는 표현·도안·사진 등을 이용하는 표 시·광고
차. 국제적 멸종 위기종의 가공품이 함유된 화장품임을 표현하거나 암시하는 표시·광고

카. 사실 유무와 관계없이 다른 제품을 비방하거나 비방한다고 의 심이 되는 표시·광고

화장품법 13 조와 시행세칙 22 조의 2 항의 핵심은 명백한 허위가 아니더라도 '소비자가 잘못 인식할 우려'가 있는 표시와 광고를 해서 는 안 된다는 것이다. 소비자가 화장품의 효능이나 성분, 원산지, 제 조방법, 인증, 명칭 등에 대해 사실이 아닌 것으로 오해할 만한 어떤 표현을 해서도 안 된다는 것이다. 그러나 소비자를 속이거나 소비자 가 오해하거나 속을 우려를 판단하는 것은 극히 주관적일 수밖에 없 다. 어떤 정보나 메시지에 대한 이해 정도나 평가는 정보를 제공하 는 정보원이나 표현방법뿐만 아니라 그것을 수용하는 소비자들에 따라서도 달라지기 때문이다. 그러므로 시장상황과 소비자의 여건 에 따라 어떤 표현이 소비자로 하여금 '오해'나 '오인'을 하게 만드는 지를 계속 검토하고 감시하는 것이 필요하다. 아울러 규제 일변도의 정책이 관련 산업의 성장을 저해하지 않도록 사업자와 소비자, 시장 감시기관이 모여 적정한 수준에서 함께 소비자의 '오해'나 '오인'의 가능성을 판단할 필요가 있다.

본 연구는 이에 화장품에 대한 표시광고 중 의약품 오인으로 식 품의약품안전처에 적발된 광고사례를 분석하여 위반광고의 문제점 을 파악하고 개선방안을 제안하고자 한다. 기능성화장품은 속성상 의약품으로 오인될 가능성이 많은데 제조업자나 판매자의 의도적인 과장이나 오도가 더해지면 소비자들이 합리적인 선에서 이를 이해 하고 선택하기가 더욱 어렵게 된다. 기능성 화장품 시장이 지속적으 로 성장하기 위해서는 소비자들이 화장품과 의약품의 경계를 이해 하고 합리적인 선택을 할 수 있도록 투명하고 객관적인 정보를 많이 제공할 수 있어야 한다. 이에 기능성 화장품의 표시와 광고를 지속 적으로 분석하고 필요한 경우 규제하거나 소비자에게 판단 가이드 라인을 교육하는 것이 필요하다. 의약품오인 광고 위반사례를 분석 하여 문제점을 파악하면 소비자의 합리적인 선택을 돕고 나아가 표 시 광고 종사자들도 표시광고 기준을 명확하게 이해하고 준수할 수 있도록 도움을 줄 수 있을 것이다.

\section{Methods}

본 연구는 화장품 표시·광고 중 소비자들이 의약품으로 오인할만 한 사례에 대해 분석하고 이를 개선하기 위한 방안을 제시하기 위한 것이다. 본 연구의 자료는 식약처에서 행정처분 공고를 받은 것으 로 공표된 표시·광고 중 식약처의 의약품안전나라(의약품종합정보 시스템)에 2019년 9월 23일자로 남아있는 자료 중에서 선택하였다. 식약처 자료에서는 업체명과, 업종, 소재지, 처분일, 종료일, 위반 내용, 처분사항, 근거법령을 확인할 수 있으나 자료가 일정 기간별 로 정리되어 있지는 않다. 그리고 데이터 기록 담당자에 따라 위반 
내용을 자세하게 적은 경우도 있으나 단순히 '화장품법 13 조 위반'과 같이 근거법령만을 표시해 놓은 것도 많아 해당광고의 구체적인 위 반내용이 어떤 것인지 확인하기 어렵다. 표시광고법 위반으로 행정 처분 공고를 받은 후 9월 23일에 식약처 사이트에 남아있는 위반건 수는 총 407 건인데 이 중 화장품법 13 조에 근거하여 의약품으로 오 인될 우려가 있는 것으로 적발된 것은 141 건이다. 본 연구에서는 이 141 건의 광고에 대해 보도자료와, 제조업자 및 판매자 사이트, 소비 자 리뷰 컨텐츠 등을 확인하여 표시·광고의 구체적인 내용을 추가로 일일이 확인하였다. 적발 건수당 여러 제품의 광고가 포함되는 경우 가 있고 하나의 제품이 여러 조항을 위반하는 경우도 있어 최종적으 로 확인이 가능한 표시·광고는 적발건수로는 141 건이나 제품수로 보면 237개였다. 최종분석은 행정처분 후 광고가 아예 모든 사이트 에서 삭제된 19 개를 제외한 218 개 제품광고를 가지고 진행하였다.

최종적으로 선정된 218 개 제품을 기준으로 먼저 화장품 종류와
위반조항, 행정처분 수위, 그리고 제품의 주요 효능과 성분을 요약 하였다. 먼저 화장품 종류는 페이스용 화장품과 헤어용, 바디용, 기 타로 크게 나누고 페이스용은 다시 클렌저와 기초제품, 색조제품, 기타로 구분하여 빈도를 표시하였다. 위반조항은 관련법 10조와 시 행세칙 22 조 위반품목과 관련법 10 조 시행세칙 19 조 위반품목으로 구분하여 제시하였고 행정처분 수위는 광고중지와 영업중지로 나누 어 제시하였다. 해당 제품이 주장하는 효능은 피부재생과 피부회복, 피부 활성화, 피부보습으로 크게 구분하고 각 효과를 위해 표시한 관련 성분의 빈도를 제시하였다. 다음에는 표시·광고의 내용 중 의 약품 오인의 우려가 있는 내용을 효능을 표현하는 텍스트와 이미지 중심으로 분석하였다. 타겟 효능에 대한 표현은 트러블 완화, 피부 재생, 항노화, 면역력 강화의 4 가지로 분류하여 문제점을 분석하였 고 아울러 표현방법에 대한 문제도 사용 전·후 비교사진 게시, 표시 위반, 금지된 용어와 이미지의 사용 세 가지로 나누어 정리하였다.

Table 1. Cosmetic category and types violating cosmetic advertisement law

\begin{tabular}{|c|c|c|c|c|c|c|c|c|}
\hline Category & & Product type & No. & $\%$ & Category & Product type & No. & $\%$ \\
\hline \multirow{22}{*}{$\begin{array}{l}\text { Face } \\
\text { products }\end{array}$} & & Foam & 9 & 4.1 & \multirow{3}{*}{ Hair products } & Shampoo & 8 & 3.7 \\
\hline & Cleanser & Gel/Moose & 1 & 0.5 & & Ample & 2 & 0.9 \\
\hline & Cleanser subtotal & & 10 & 4.6 & & Mist & 2 & 0.9 \\
\hline & \multirow{10}{*}{ Skin-care } & Toner & 11 & 5.0 & \multirow{3}{*}{ Hair subtotal } & Hair dyes & 3 & 1.4 \\
\hline & & Emulsion & 2 & 0.9 & & & 15 & 6.9 \\
\hline & & Essence & 36 & 16.5 & & Washer & 6 & 2.8 \\
\hline & & Cream & 50 & 22.9 & \multirow{7}{*}{$\begin{array}{l}\text { Body } \\
\text { products }\end{array}$} & Lotion & 2 & 0.9 \\
\hline & & Sun cream & 4 & 1.8 & & Cream & 10 & 4.6 \\
\hline & & Skin Oil & 2 & 0.9 & & Mask & 2 & 0.9 \\
\hline & & Ample & 18 & 8.3 & & Gel/Moose & 4 & 1.8 \\
\hline & & Mist & 7 & 3.2 & & Oil & 3 & 1.4 \\
\hline & & Gel & 3 & 1.4 & & Pack & 2 & 0.9 \\
\hline & & Set & 3 & 1.4 & & Mist & 1 & 0.5 \\
\hline & Skincare subtotal & & 136 & 62.4 & Body subtotal & & 30 & 13.8 \\
\hline & & Makeup base & 1 & 0.5 & \multirow[t]{9}{*}{ Others } & & 1 & 0.5 \\
\hline & Make-Up & Foundation & 5 & 2.3 & & & & \\
\hline & & Lipstick & 1 & 0.5 & & & & \\
\hline & Make-up subtotal & & 7 & 3.2 & & & & \\
\hline & & Facial mask & 16 & 7.3 & & & & \\
\hline & Others & Peeling gel & 2 & 0.9 & & & & \\
\hline & & Perfume & 1 & 0.5 & & & & \\
\hline & Others subtotal & & 19 & 8.7 & & & & \\
\hline Face subtotal & & & 172 & 78.9 & & & & \\
\hline Total & & & & & & & 218 & 100 \\
\hline
\end{tabular}


분석 내용에 근거하여 의약품 오인의 우려가 있는 표시·광고의 문제 점을 요약하고 앞으로의 개선방안에 대해 제언하였다.

\section{Results \& Discussion}

\section{1. 위반광고의 화장품 종류와 위반조항}

먼저 적발된 218 개 화장품의 종류를 보면 다음 Table 1 과 같다. 분석대상 화장품은 크게 페이스용과 헤어용, 바디용 제품으로 나뉘 고 페이스용 제품은 기초제품과 색조제품, 클렌징 제품, 기타의 네 가지 종류로 크게 구분된다. 행정처분을 받은 제품 중 페이스용 제 품이 $78.9 \%$ 로 가장 많았고 그 다음은 바디용품 $13.8 \%$, 헤어용품 $6.9 \%$ 순이었다. 페이스용 제품 중에서는 $79 \%$ 가 기초 제품이었고 클렌징 제품이 $5.8 \%$, 색조제품이 $4.1 \%$, 기타가 $11 \%$ 였다. 헤어용품 중에서는 샴푸가, 바디용품 중에서는 크림류가 가장 많았다. 페이스 용 기초제품에 속하는 크림류와 에센스류, 앰플류 기초제품은 104 건인데 이 세 제품이 전체 적발건수의 거의 절반인 $47.7 \%$ 를 차지하 고 있어 이 제품군에서 의약품 오인의 표시·광고가 발생할 가능성이 높음을 시사한다.

의약품 오인 표시·광고로 행정처분을 받은 제품 중 분석대상인 218 개 제품이 위반한 조항은 Table 2 와 같다. 하나의 조항만 위반 한 경우가 169 건으로 $75.4 \%$ 이고 두 개 조항을 위반한 경우가 44건 (19.6\%), 세 개 조항을 위반한 경우가 9건(4.0\%)이다. 화장품책임판 매 업종의 화장품법 제 13 조 및 화장품 시행규칙 제 22 조에서 제 2 항
가목 '의약품으로 잘못 인식할 우려가 있는 내용, 제품의 명칭 및 효 능·효과 등에 대한 표시·광고를 하지 말 것'이라는 항목 위반건수가 163 건으로 전체의 $55.4 \%$ 를 차지할 정도로 가장 많다. 시행세칙 22 조 2 항 가목만 위반한 건수가 113 건이지만 이와 함께 다른 항목을 이중, 삼중으로 위반한 건수까지 합치면 163 건에 달한다.

두 번째로 높은 비율을 차지하는 것은 사목 '소비자 오인' 항목으 로 해당항목 단일위반건수가 42건, 중복 위반건수가 36건으로 총 78 건(26.5\%)이다. 2 개 이상의 조항을 위반한 건수 중에서 가목과 사목을 위반한 건수는 33 건으로 전체 위반건수의 $14.7 \%$ 를 차지한 다. 사목은 '사실과 다르거나 부분적으로 사실이라고 하더라도 전체 적으로 소비자가 잘못 인식할 우려가 있는 표시·광고 또는 소비자를 속이거나 소비자가 속을 우려가 있는 표시·광고를 하지 말 것'이라는 조항이다. 의약품 오인 광고의 대부분이 22 조 나목이나 다목, 바목 과 같이 해석이 비교적 명백한 조항보다 가목과 사목처럼 해석기준 이 불분명한 조항 위반으로 적발된 것을 알 수 있다. 시행세칙 다목 의 불분명한 의료기관과 의료인의 추천이나 카목의 경쟁사 비방으 로 적발된 광고는 하나도 없었다.

Table 3 에 정리한 바와 같이 적발된 218 개 제품에 대한 행정처분 은 모두 220 건이다. 이 중 가장 높은 행정처분 비율이 가장 높은 처 분은 해당제품 광고업무정지 3 개월로 전체의 $58.2 \%$ 를 차지한다. 판 매업무 정지 처분을 받은 제품의 비율은 $2.3 \%$ 에 불과하고 3 개월을 초과하는 해당품목 광고업무 정지처분을 받은 제품도 $10.5 \%$ 에 불과 하다. 광고업무정지 3 개월 처분은 대부분 화장품법 제 13 조 및 화장 품 시행규칙 제 22 조 각 2 호 가목인 '의약품 오인'의 경우 해당하는 표

Table 2. Articles violated by cosmetic advertisement as revealed by KFDA

\begin{tabular}{|c|c|c|c|c|}
\hline Law \& Rules & Item & Contents of violation & No. & $\%$ \\
\hline \multirow{18}{*}{ Article 13 (law) } & $\mathrm{Ga}$ & Medical misconception & 113 & 50.4 \\
\hline & $\mathrm{Na}$ & Functional misconception & 4 & 1.8 \\
\hline & Sa & Consumer misconception & 42 & 18.8 \\
\hline & $\mathrm{Ba}$ & Cliquish advertising & 2 & 0.9 \\
\hline & Ah & Ads. of unidentified cosmetics & 8 & 3.6 \\
\hline & 1 Violation subtotal & & 169 & 75.4 \\
\hline & \multirow{8}{*}{2 Item violation } & $\mathrm{Ga} \& \mathrm{Na}$ & 5 & 2.2 \\
\hline & & $\mathrm{Ga} \& \mathrm{Da}$ & 3 & 1.3 \\
\hline & & $\mathrm{Ga} \& \mathrm{Ba}$ & 2 & 0.9 \\
\hline & & $\mathrm{Ga} \& \mathrm{Ah}$ & 6 & 2.7 \\
\hline & & $\mathrm{Ga} \& \mathrm{Sa}$ & 24 & 10.7 \\
\hline & & $\mathrm{Ga} \& \mathrm{Ca}$ & 1 & 0.4 \\
\hline & & $\mathrm{Sa} \& \mathrm{Ah}$ & 2 & 0.9 \\
\hline & & $\mathrm{Ba} \& \mathrm{Sa}$ & 1 & 0.4 \\
\hline & \multicolumn{2}{|l|}{2 Violations subtotal } & 44 & 19.6 \\
\hline & \multirow{2}{*}{$3 \&$ more item violation } & $\mathrm{Ga}, \mathrm{Na}, \& \mathrm{Sa}$ & 1 & 0.4 \\
\hline & & $\mathrm{Ga}, \mathrm{Na}, \mathrm{Sa}, \mathrm{Ah}$ & 8 & 3.6 \\
\hline & \multicolumn{2}{|l|}{3 Violations subtotal } & 9 & 4 \\
\hline $\begin{array}{l}\text { Article } 10 \text { (law) \& } 19 \\
\text { (enforcement rules) }\end{array}$ & \multicolumn{2}{|c|}{ Labelling and marking of cosmetic packaging } & 2 & 0.9 \\
\hline \multicolumn{3}{|l|}{ Total } & 224 & 100 \\
\hline
\end{tabular}


시·광고를 한 경우이다. 가목을 제외하고 하나만 위반했을 경우에는 2 개월, 가목을 포함해 두 개 이상을 위반했을 경우 대체로 광고업무 정지 3 개월 이상의 처분을 받는 것으로 나타난다.

가장 과중한 처분인 3 개월간의 전품목 판매업무정지 처분을 받은 표시·광고는 헤어 염료 제품에 대한 것으로 기능성화장품으로 심사 가 완료되지 않은 해당제품을 기능성제품인 것처럼 판매하여 화장 품법 제 4 조 제 1 항을 위반한 것으로 적발된 것이다. 이는 외국에서 수입한 오일 제품으로 수입화장품 판매시 의약품으로 오인할 수 있 는 표현을 사용하여 화장품법 제 13 조 및 화장품 시행령 제 22 조 제 2 호 가목을 위반하였다. 판매업무정지 15 일과 1 개월 7 일 처분을 받 은 제품은 동일업체의 헤어 염료 제품으로 수입화장품 포장의 기재· 표시 등에 관한 화장품법 제 10 조 및 화장품 시행령 제 19 조를 위반 한 것이다. 의약품 오인 우려만으로 적발된 표시·광고보다 기능성화
장품이 아닌 것을 기능성화장품인 것처럼 명백히 허위로 표시했거 나 수입품에 대한 표시를 잘못한 경우 행정처분 수위가 높아지는 것 을 알 수 있다.

다음은 218 개 제품의 표시·광고에 나타난 제품의 성분을 분석하 였다. 분석대상 자료에서 확인이 가능한 성분은 모두 379 개에 달할 정도로 매우 다양하였다. 379 개 성분 중 5 회 이상 나타난 성분만 정 리하면 Table 4 와 같다. Table 4 를 보면 빈도가 높은 상위 10 가지 성 분이 183 회에 걸쳐 나타나 전체의 $48.3 \%$ 를 차지하고 있다. 가장 많 이 광고되는 성분은 시카류이다. 이는 병풀, 마데카, 센텔라 등 다 양한 이름으로 불리며 분석 대상 제품 광고에서 44 회 나타난다. 다 음은 히알루론산(AHA, BHA, PHA)과 복합단백질류(펩타이드, 아 미노산, 글루타치온 등)로 각각 20 회와 18 회 나타나고 있다. 이 외 에 10 회 이상 나타나는 성분은 인체유래단백질류(EGF, FGF, KGF,

Table 3. Administrative penalty for the advertisements as revealed by KFDA

\begin{tabular}{|c|c|c|c|c|}
\hline Disposition penalty & Category & Period & No. & $\%$ \\
\hline \multirow{5}{*}{ Suspension of sales } & All items & 3 months & 1 & 0.5 \\
\hline & \multirow{4}{*}{ Uncovered items } & 15 days & 1 & 0.5 \\
\hline & & 1 month and 7 days & 1 & 0.5 \\
\hline & & 2 months & 2 & 0.9 \\
\hline & & 3 months & 1 & 0.5 \\
\hline Subtotal & & & 6 & 2.3 \\
\hline \multirow{5}{*}{$\begin{array}{l}\text { Suspension of the } \\
\text { advertisement }\end{array}$} & \multirow{5}{*}{ Uncovered items } & 1 month & 1 & 0.5 \\
\hline & & 2 months & 62 & 28.2 \\
\hline & & 3 months & 128 & 58.2 \\
\hline & & 4 months & 1 & 0.5 \\
\hline & & 4 months and 15 days & 22 & 10 \\
\hline Subtotal & & & 214 & 97.7 \\
\hline Total & & & 220 & 100 \\
\hline
\end{tabular}

Table 4. Ingredients involved in cosmetic advertisement as revealed by KFDA

\begin{tabular}{|c|c|c|c|c|}
\hline Effect & Category & Ingredients & No. & $\%$ \\
\hline Skin repairing & Natural extract & Cica, Madeca, Centella etc. & 44 & 24.0 \\
\hline Skin repairing & Protein & Hyaluronic acid (AHA, BHA, PHA) & 22 & 12.0 \\
\hline Skin repairing & Protein & $\begin{array}{l}\text { Protein complex (Peptide, Amino acid, Glutathione, } \\
\text { etc.) }\end{array}$ & 20 & 10.9 \\
\hline Skin repairing & Protein & Human-origin proteins (EGF, FGF, KGF, VGF, VGEF) & 18 & 9.8 \\
\hline Skin activating & Protein & Collagen & 12 & 6.6 \\
\hline Skin repairing & Vitamin & Vitamin & 11 & 6.0 \\
\hline Skin repairing & Natural extract & Houttuynia cordata & 11 & 6.0 \\
\hline Skin hydrating & Protein & Ceramide & 10 & 5.5 \\
\hline Skin repairing & Vitamin & Panthenol & 7 & 3.8 \\
\hline Skin whitening & Vitamin & Niacinamide & 6 & 3.3 \\
\hline Skin repairing & Natural extract & Arnica & 6 & 3.3 \\
\hline Skin repairing & Natural extract & Mugwort extract & 6 & 3.3 \\
\hline Skin repairing & Protein complex & Scolofendracin & 5 & 2.7 \\
\hline Skin repairing & Natural extract & Calendula oil & 5 & 2.7 \\
\hline Total & & & 183 & 100 \\
\hline
\end{tabular}


$\mathrm{VGF}, \mathrm{VGEF}$ ), 콜라겐류, 비타민류, 어성초류, 세라마이드이다.

상위 10 개 성분들 대부분은 의료나 제약업계에서 상처치료나 피 부보습 및 피부재생을 위해 사용하던 성분들이다. 특히 히알루론산 이나 펩타이드, 글루타치온, $\mathrm{EGF}$ 등은 피부내에 존재하는 성분이거 나 체내에서 합성되는 항산화제나 단백질 같은 것들이다. 예전에는 이런 성분은 가격이 비싸거나 합성하기가 어려웠고 또 외부에서 피 부에 흡수시키기 위해서 특별한 기술이 필요했기 때문에 주로 제약 업체에서 의약품으로 생산해 유통해왔다. 그러나 원료의 추출과 합 성, 주사기술이 향상되면서 화장품 형태로 개발되고 있다. 분석 대 상 자료에서는 이들 성분이 대개 손상된 피부를 회복시키는 효과/효 능이 있는 것으로 광고하고 있고 카테고리상 '단백질' 성분 또는 '천 연 추출물'로 표현되고 있다.

\section{2. 의약품 오인 표시·광고의 효능 표현}

의약품 오인으로 행정처분을 받은 표시·광고에서 소비자오인의 핵심은 제품의 효능에 관한 것이라고 할 수 있다. 그러므로 소비자 들이 일반 화장품에 기대하는 수준을 넘어 의약품과 같은 수준의 치 료를 하는 것으로 제품의 효능을 오인할 우려가 있는지를 판단하는 것이 중요하다. 사업자들은 다양한 이미지와 용어를 사용하여 효능 의 수준을 과장하거나 오해할 수 있게 만들고 종종 의약품 수준의
효과를 암시하기 때문이다. 여기에서는 분석대상 자료를 타겟 효능 과 효능 표현방식에 따라 Table 5 와 같이 정리하고 자주 나타나는 소비자가 오인할만한 효능 표현 사례를 제시하였다. Table 5에 따 르면 의약품 오인 광고에서 가장 많이 강조하는 효능은 피부 트러블 개선과 피부재생효과, 항노화 효과, 면역력 증진 효과 순서로 각각 $93,70,66$ 회, 44회 나타나고 있다. 의약품 오인의 우려가 있는 화 장품은 일반 화장품보다 기능성화장품일 가능성이 높기 때문에 일 반 화장품에 비해 기능을 강조하는 것은 자연스럽다. 그러나 소비자 들이 의약품에 준하는 효능을 기대하도록 만드는 명백하고 의도적 인 표현들이 나타나고 있다.

\section{1) 트러블(뾰루지, 아토피, 여드름) 개선 \& 가려움 완화}

뾰루지나 아토피, 여드름 개선과 관련된 트러블을 완화 또는 상 태를 개선시킨다는 효능은 의약품 오인 위반광고에서 가장 자주 강 조되는 표현이다(Table 5). 트러블이 가라앉고 '여드름이 진정된다' 는 표현을 하거나 아예 '여드름 화장품'이라는 용어를 사용하기도 하 였다. '아토피 알러지 탈출'이라는 표현으로 아토피를 치료했다는 암 시를 주는 표현도 있었다. 제품을 사용하고 나서 여드름이 가라앉거 나 아토피에 효과가 있었다는 소비자 후기를 옮겨 게재하기도 하였 다. 여드름이나 아토피는 의료적 처치가 필요한 부분임에도 불구하

Table 5. Cosmeceutical effect expression of KFDA-revealed advertisements

\begin{tabular}{|c|c|c|c|}
\hline & Expression and words used in advertisements & No. & $\%$ \\
\hline \multirow{13}{*}{$\begin{array}{l}\text { Expression of target } \\
\text { effect }\end{array}$} & Care of skin trouble (pimple, atopy, acne) \& relaxing itchy & 93 & 19.4 \\
\hline & $\begin{array}{l}\text { Skin repairing (recovering scar, scar management, skin barrier } \\
\text { protecting, skin turn-over cycle management) }\end{array}$ & 70 & 14.6 \\
\hline & Anti-aging (wrinkle reduction, skin tightening) & 66 & 13.8 \\
\hline & $\begin{array}{l}\text { Immune enhancement (anti-inflammatory, anti-bacterial, anti- } \\
\text { cancer) }\end{array}$ & 44 & 9.2 \\
\hline & Reducing of skin fever (face flush, congenital fever) & 28 & 5.8 \\
\hline & Diet (cellulite reducing, swelling relief) & 23 & 4.8 \\
\hline & Moisturizing (dead skin cell relaxing, skin texture management) & 23 & 4.8 \\
\hline & Whitening/blemish control & 19 & 4.0 \\
\hline & Blood circulation improving, fatigue recovery & 20 & 4.2 \\
\hline & $\begin{array}{l}\text { Alopecia (prevention/relaxing), hair growth, management of hair } \\
\text { thickness }\end{array}$ & 14 & 2.9 \\
\hline & Detox/body wastes removing & 11 & 2.3 \\
\hline & Sebum control/pore tightening & 8 & 1.7 \\
\hline & Chest volume up & 2 & 0.4 \\
\hline \multirow{9}{*}{ Expression mode } & Exaggerated before and after picture/writing fake reviews & 11 & 2.3 \\
\hline & Insisting no harmful ingredients at all & 6 & 1.3 \\
\hline & $\begin{array}{l}\text { No information of functional ingredient or location, misinformed on } \\
\text { usage \& capacity, misuse of the FDA's official permission }\end{array}$ & 6 & 1.3 \\
\hline & Use of banned words like a 'best of the best', 'excellent','top' & 4 & 0.8 \\
\hline & Tactful fakery using pregnancy/fetus & 3 & 0.6 \\
\hline & Insisting post-treatment skin care & 2 & 0.4 \\
\hline & Use of doctor and medical care & 2 & 0.4 \\
\hline & Others, unidentified & 25 & 5.2 \\
\hline & Total & 480 & 100 \\
\hline
\end{tabular}


고 '탈출'이나 '가라앉다' 또는 '효과를 봤다', '상처가 치료되었다' 라 는 식의 표현 때문에 소비자들은 화장품으로 치료 또는 완치의 효과 를 볼 수 있는 것처럼 느낄 수 있다

2) 피부재생(상처회복, 흉터개선, 피부장벽 강화, 턴오버주기 개선) 의약품 오인으로 적발된 표시·광고에서 두 번째로 자주 언급되는 효능은 피부재생과 관련된 내용이다(Table 5). 상처회복, 흥터개선, 피부장벽 강화, 턴오버주기 개선 등의 용어도 피부재생을 암시하는 내용들이다. 진피층의 세포 구조를 그림으로 보여주면서 '세포활성 화, 세포성장 활발, 피부층 재생'이라고 표현하거나 '피부 세포 재생 에 뛰어난/탁월한 효과'라는 표현, '손상된 피부 집중 재생을 위한 수 면케어 마스크'라는 표현 등 피부세포를 재생시키는 놀라운 효과가 있는 것처럼 묘사하고 있다. '세포'라는 생물학적 용어와 '재생'이라 는 치유를 암시하는 용어의 혼합은 소비자로 하여금 자연스럽게 의 료적 효과를 상상하게 만든다. 또한 ' 26 분만에 진피층 도달', '상처치 유에 도움'과 같은 용어를 사용하여 소비자들이 제품을 치유효과가 있는 의약품으로 오인할 소지를 만들고 있다.

\section{3) 항노화 기능(주름, 탄력 강화)}

피부와 관련된 노화의 대표적인 증상은 주름과 피부의 탄력 약화 이다(Table 5). 피부보습이 주름예방과 탄력유지에 효과가 있는 것 으로 알려져 있기 때문에 보습기능을 강화하면 피부노화 예방 또는 노화방지에 도움이 된다고 말할 수 있다. 다만 이미 노화의 증상인 주름이 생겼거나 탄력이 약화된 경우 이를 개선할 수 있는 효능, 예 를 들어 지나친 리프팅(lifting) 효과를 기대하게 만드는 표현들이 문 제가 되고 있다. 한 제품은 제품이 '양악주사'에 해당하는 효과가 있 는 것처럼 광고하였고 또 다수의 광고가 효과가 과장된 사용전후 사 진이나 후기를 제시하였다. 또 '금사 리프팅 케어'라는 단어를 사용 해 '실 리프팅 수술'효과를 연상하게 만드는 광고도 문제가 있는 것 으로 나타나고 있다. '주름이 채워지고 속눈썹이 자라는 역주행 대란 템'과 같은 표현도 이미 생긴 주름을 개선할 수 있는 효과가 있는 것 으로 소비자들이 오인할 소지가 있다.

\section{4) 면역력 증진(항염, 항균, 항암 효과)}

면역력이라는 단어는 소비자들의 명백하게 의료용어로 인식하 는 용어이다. 항염, 항균이라는 용어도 마찬가지이다. 따라서 의약 품 오인 광고 중 면역력 증진이나 항염, 항균 효과라는 용어를 사용 한 광고들은 소비자 입장에서는 가장 의약품으로 오인할 우려가 큰 광고라고 할 수 있다. 그런데 이런 효능이 피부트러블 개선, 피부재 생, 항노화 기능에 이어 4 번째로 많이 언급되고 있으며 44회나 사용 되고 있다(Table 5). 관련 표현을 보면 '피부 면역력 향상 Immunity Upgrade', '세균에 감염이 되거나 면역반응을 통해 생긴 염증을 가 라앉히는데 도움', '세균에 의한 질염 예방에 도움', '소염작용, 염증 완화작용, 항균 작용을 하며 ' 등 병의원에서 할만한 표현들을 하고
있다. 심지어 '암세포 등을 죽이는 전자파의 일종'이라는 표현으로 항암 효과를 연상하게 하는 표현도 존재하였다.

\section{5) 기타 효능(피부열 감소, 다이어트 효과, 혈행개선 등)}

의약품 오인광고의 표현들 중 피부열 감소와 혈행개선, 다이어트 효과, 미백효과/잡티제거라는 표현도 20 회 이상 나타나고 있다. 피 부열 감소에 대해서는 '얼굴이 후끈거리고 가려웠던 게 없어져서 감 탄이 '라는 표현이나 '피부온도 감소'라는 표현이, 다이어트 효과에 대해서는 '원적외선 방식으로 얼굴에 미세한 진동을 일으켜 피부에 스며들 수 있도록 도와줍니다'와 '붓기제거'라는 표현이, 혈행 개선에 대해서는 '혈액 순환 활성화', '두피의 혈액순환을 원활히 하고 ', ' 혈액 순환을 촉진하고 해열, 항균 작용을 함 과 같은 표현이, 미백 효과/잡티제거에 대해서는 ' 24 시간 지속적이고 효과적인 화이트닝 을 원할 때', '기미 검버섯 원인, 검버섯 없애는 방법', '독특한 라이트 리플렉팅 콤플렉스가 피부 나이를 되돌려 빛나게 하고...', '기미, 주 근깨 등의 색소침착 완화'라는 표현이 사용되고 있다.

의약품 오인 광고에서 강조하는 효능 외에 표현방식에 있어서의 문제점을 살펴보면 다음 Table 5 와 같다. 가장 문제가 되는 것은 효 과가 과장된 사용 전·후 사진이나 후기를 제시하는 것이다. 적발된 의약품 오인 광고에서 화장품 사용 후 주름이 펴지거나 탄력 또는 홍조가 개선된 효과를 시각적으로 제시한 경우가 11 회 나타났다. 다 음은 특정 유해성분을 제외했다고 주장하는 표현이 6 회, 기능성 성 분 또는 소재지를 표시하지 않거나 용법용량을 다르게 기재하는 등 표시위반 관련 사례가 6 회, '최상', '탁월', '최고'라는 금지된 표현을 사용한 사례가 4 회로 나타났다.

\section{1) 사용 전·후 비교사진이나 후기 게시}

화장품법 시행세칙에 따르면 사실과 다르거나 부분적으로 사실이 라고 하더라도 전체적으로 소비자가 잘못 인식할 우려가 있는 표시· 광고 또는 소비자를 속이거나 소비자가 속을 우려가 있는 표현은 금 지되어 있다. 그런데 전체적으로 보아 소비자가 오인할 가능성이 큰 트러블(뾰루지, 아토피, 여드름) 개선효과를 보여주는 사진과, 피부 열(홍조, 태열)과 주름이 눈에 띄게 감소된 사진, 가슴볼륨이 확대된 사진, 미백 효과가 과장된 화장품 사용전후 사진이 여전히 사용되고 있었다. 효과를 구체적으로 이야기하지 않더라도 화장품 사용 전후 의 비교사진은 소비자들이 의약품 수준 이상의 효과를 기대하게 만 들 정도로 과장되어 있다. 또한 여드름이나 피부 트러블이 해결되었 다는 내용의 소비자 체험 후기도 게재하고 있다. 광고에 따라 개인 에 따라 효과에 차이가 있을 수 있다는 문장이 작게 추가되어 있는 경우도 있었다.

2) 표시 위반

표시 위반으로 분류된 6 건은 화장품법 제 10 조 및 시행령 제 19 조 위반에 해당하는 것들이다. 제조회사의 소재지를 기재하지 않았고, ' 
기능성화장품'이라는 글자를 기재하지 않았으며, 용법·용량을 심사 받은 내용과 다르게 기재한 것이 문제가 되었다. 이 외에도 제품 포 장에 '사용할 때 주의사항'중 일부 '공통사항'을 기재하지 않았거나 제품포장에 용법·용량을 기능성화장품 심사받은 용법·용량과 다르 게 기재하였고, 사용할 때 주의사항을 [화장품법 시행규칙] 제 19 조 제3항과 다르게 기재하였으며, 바코드를 기재하지 않은 경우도 있 다. '식약처 의약외품 정식허가'라는 표현이 소비자 오인의 가능성이 있어 지적되었는데 이는 소비자들이 기능성화장품과 달리 '의약외 품'이라는 단어를 의약품과 혼동할 우려가 있기 때문인 것으로 보인 다.

\section{3) 금지된 용어와 이미지의 사용}

화장품법 시행세칙 22 조 2 항 바목에 따르면 경쟁상품과 비교하여 최고 또는 최상이라는 표현을 사용할 때는 이를 정확하게 확인할 수 있는 수치 등을 제시하도록 되어 있다. 그런데 이런 근거 없이 최고/ 최상이라는 절대적인 표현이 사용되고 있다. 또한 시행세칙 22 조 2 항 다목에 '의사-치과의사·한의사·약사·의료기관·연구기관 또는 그 밖의 자(할랄 화장품, 천연화장품 또는 유기농 화장품 등을 인증·보 증하는 기관으로서 식품의약품안전처장이 정하는 기관은 제외한다) 가 이를 지정·공인·추천·지도·연구·개발 또는 사용하고 있다는 내용 이나 이를 암시하는 표현을 하지 못하게 되어 있음에도 불구하고'의 사, 의료기관이 개발, 사용하고 있다'는 내용이나 이를 암시하는 표 현도 나타나고 있다. 나아가 '임산부는 물론 우리 아이까지 사용할 수 있는 안전한 성분'과 같은 객관적으로 확인되지 않은 표현을 사용 하여 소비자들이 화장품을 의약품으로 오인하고 안전성을 과신하게 만들 우려를 낳고 있다.

\section{Conclusion}

식품의약품안전처에 의약품 오인으로 행정처분을 받은 표시·광고 사례를 분석한 결과는 다음과 같다. 우선 해당 화장품 중 $78.9 \%$ 가 페이스용 화장품이고 이 중 $79 \%$ 가 기초제품인 것으로 나타났다. 특 히 기초제품 중 에센스와 크림류, 앰플류 제품이 거의 절반인 $47.9 \%$ 에 달해 이들 제품 유형에서 의약품 오인 우려가 많이 발생함을 알 수 있다. 위반조항은 대부분 화장품법 13 조, 시행세칙 22 조 2 항의 가목이고 가목만 위반하거나 가목과 다른 항목을 중복 위반한 경우 가 전체 위반건수의 $73 \%$ 에 해당하였다. 의약품 오인 표시·광고에 서 제시된 성분은 379 개에 달할 정도로 매우 다양하였으나 가장 많 이 등장한 성분은 시카류(병풀, 마데카, 센텔라), 히알루론산(AHA, $\mathrm{BHA}, \mathrm{PHA}$ ), 복합단백질류(펩타이드, 아미노산, 글루타티온 등), 인 체유래단백질류(EGF, FGF, KGF, VGF, VGEF), 콜라겐류, 비타민 류, 어성초류, 세라마이드 순이었다. 의약품 오인 표시·광고에 대한 행정처분은 판매업무중지가 $2.3 \%$ 였고 대부분 해당제품광고업무중
지 처분을 받았는데 3 개월 이하 중지가 $87.2 \%$ 로 대다수를 차지하였 다.

의약품 오인 표시·광고에서 가장 많이 강조하는 효능은 피부 트러 블 개선과 피부재생효과, 항노화 효과, 면역력 증진 효과 순서로 각 각 $93,70,66$ 회, 44회 나타났다. 의약품 오인의 우려가 있는 화장 품은 일반 화장품보다 기능성화장품일 가능성이 높기는 하나 소비 자들이 의약품에 준하는 효능, 때로는 그 이상의 효과를 기대하도록 만드는 명백하고 의도적인 표현들이 다수 나타나고 있다. 표현방식 에 있어서도 효과가 과장된 사용 전·후 비교사진이나 후기를 제시하 여 소비자들이 직관적으로 과도한 효능을 기대하도록 만들거나 특 정 유해성분을 제외했다고 주장하면서 안전성을 강조하거나 명확한 근거 제시 없이 최상 또는 최고와 같은 금지된 용어를 사용하거나 표시의무를 위반한 사례들이 나타났다.

분석결과를 중심으로 의약품 오인 표시·광고의 문제점을 정리하 고 개선방안을 제안하면 다음과 같다. 첫째, 화장품 효능에 대한 표 시·광고 지침이 여전히 구체적이지 않다. 식약처 기준상 의약품과 일반 화장품의 중간에 기능성화장품이 위치해 있기 때문에 화장품 의 효능에 대한 표시 가이드라인을 정하는 것이 쉽지는 않다. 따라 서 행정처분을 받은 제품의 경우에도 명백하게 의료적 효과임을 명 시한 허위표시 때문이 아니라 '의료적 효과'가 있는 것으로 착각하 게 하는 표현을 사용했다는 점에서 적발된 것이 대부분이다. 화장품 법 2조 2항에 따르면 기능성화장품은 피부의 미백이나 주름개선에 ' 도움'을 주거나, 자외선으로부터 '보호'해주는 제품, 모발의 색상 변 화/제거 또는 영양공급에 '도움'을 주는 제품, 피부나 모발의 기능 약 화로 인한 건조함, 갈라짐, 빠짐, 각질화 등을 방지하거나 개선하는 데에 '도움'을 주는 제품으로 정의되어 있기 때문에 소비자들이 이를 의약품으로 오인하는가 아닌가는 어떤 문제를 '(완전히) 치료하는 제 품인가' 아니면 '도움을 주는 제품인가'를 판단하는 문제이다. 소비자 입장에서는 어떤 질병에 대한 의료적 효과에 대해서도 언제나 $100 \%$ 를 기대하는 것은 아니기에 '도움이 된다'라는 표현을 '(의료적) 효과 가 있다'는 표현의 연장선상에서 인식할 수밖에 없고 이는 기능성화 장품과 의약품의 경계가 태생적으로 모호할 수밖에 없음을 의미한 다.

그러나 화장품법에 정해진 기능성화장품의 효능을 보면 화장품의 효과는 비교적 제한적이다. 본 연구의 결과에 의하면 의약품 오인 이 주로 발생하는 제품은 페이스 기초제품이므로 주로 자외선을 차 단하고 색소침착을 억제하여 미백에 도움을 주거나 피부탄력 개선, 주름완화 및 개선이 기능성화장품이 가져올 수 있는 효과에 해당한 다. 그러므로 위반 사례에서 많이 보이는, 여드름과 아토피 같은 피 부 트러블 해결이나 면역력 증진, 피부세포 재생, 혈행 개선, 항노 화 기능과 항염/항균 기능과 같은 효과는 기능성화장품에서는 기대 하기 힘든 것들이다. 그러므로 화장품 효능 표시·광고 가이드라인은 미백이나 탄력과 관련된 표현 외에 소비자들이 일상적으로 의료 용 어로 인식하는 표현인 '면역력', '세포재생', '혈행개선', '항균, 항염'과 
같은 용어나, '여드름이나 아토피' 등 피부 트러블을 치료한 것처럼 오인하게 하는 표현을 쓰지 않도록 구체적으로 적시하여야 한다. 또 한 기능성화장품의 효과는 주름이나 탄력의 사후 개선이나 피부 트 러블의 치료가 아닌, 주로 예방적 기능임을 정의상에 명시하는 것도 필요하다.

둘째, 의약품 오인 표시·광고에 대한 행정처분의 실효성에 문제 가 있을 수 있다. 위반사례의 $87.2 \%$ 는 해당제품에 대한 3 개월 이내 광고업무중지 처분을 받았는데 일반적으로 한 광고가 집행되는 기 간이 한 계절 정도이고 회사마다 가지고 있는 브랜드의 수가 다양함 을 감안하면 이는 기업에 큰 영향을 미칠 수 없는 처분이다. 초기에 화장품 효능을 과장하여 시장에서 인지도를 높이고 난 후에는 식약 처에 누군가가 신고를 접수하고 광고집행중지 처분을 받더라도 주 력제품이 아닌 한 타격이 크지 않다. 비슷한 유형의 의약품 오인 표 시·광고가 끊임없이 되풀이되는 것도 이 때문이다. 현실적으로 모든 화장품 표시·광고에 대하여 전수심사를 할 수 없을 바에야 소비자의 의약품 오인에 대한 판단을 사업자에게 맡기고 어느 정도 자율규제 를 하게 하되 만일 적발되었을 경우에는 처분을 강화하는 것이 필요 하다.

셋째, 소비자를 대상으로 화장품 효능에 대한 소비자 오인의 기준 을 지속적으로 조사하고 이에 대한 자료를 사업자 및 소비자와 공유 해야 한다. 커뮤니케이션에서 메시지의 이해도와 수용성은 정보원 의 신뢰도나 메시지의 유형뿐만 아니라 메시지 수신자의 인지적 수 준과 기타 특성에 따라서도 달라진다. 화장품 소비자의 지식수준과 피부상황 등이 매우 다르기 때문에 평균적인 소비자들이 어떤 용어 와 표현을 의료적 효과로 인식하고 어떤 것을 화장품의 기능으로 인 식하는지에 대한 조사가 필요하다. 예를 들어 위반사례에 나타난 '임 산부에게도 안전하다'라는 식의 표현은 그 자체로 문제가 없지만 소 비자에게 '극단적 안전감'을 주는 표현일 수 있고 '아토피 탈출'이라 는 표현은 의료적 처치가 아닌 화장품으로 아토피를 치료할 수 있다 는 인식을 갖게 만드는 표현일 수 있다. 특히 위반사례에서 많이 나 타나고 있는 특정 성분들(시카류, 히알루론산 등)은 화학적, 생물학 적 용어로 표현되면 소비자에게 과학적으로 검증된, 의료 효과가 있 는 성분으로 인식될 가능성이 있으므로 이를 사용하는 화장품의 표 시·광고에 대해서는 신고가 접수되지 않더라도 조사와 검사가 이루 어져야 한다.

넷째, 식약처에 화장품 표시·광고 위반사례에 대한 더 구체적인 기록을 공개하여야 한다. 현재 식약처 자료에는 행정처분을 받은 위 반사례가 어떤 제품인지, 어느 지역에서 발생했는지, 화장품법 몇 조 몇 항을 위반했는지 나와 있다. 그러나 어떤 성분이 왜 문제가 되 었는지, 어떤 표현이 왜 처분을 받았는지에 대한 기록은 담당자에 따라 제 각각이어서 화장품 표시·광고를 집행하는 사업자 입장에 서 참고하기가 어려운 상황이다. 소비자 오인여부를 판단하는 작업 은 주관적인 요소가 강하기 때문에 광고를 집행하는 사업자도 제대 로 된 광고를 하기 위해 참조할만한 위반사례를 찾아보고 똑같은 실
수를 저지르지 않도록 해주어야 한다. 그런데 일단 행정처분을 받은 광고는 광고 현장에서 일정 기간 후 삭제되기 때문에 개별 사업자가 다양한 참고자료를 구하기가 어렵다. 식약처에서 행정처분을 내린 표시·광고에 대해서는 위반사항을 구체적으로 기록하고 시행세칙 조항별로 공개하는 것이 필요하다.

기능성화장품은 시장과 소비자의 필요에 따라 개발된 것으로 일 반화장품과는 다른 기능이 있어 식약처가 판매를 허가한 화장품이 다. 따라서 제품의 기능에 대한 어느 정도의 표시와 광고가 필요 할 수밖에 없다. 또한 의약품과 화장품의 성격을 동시에 가지고 있 어 표시와 표현에서 그 경계를 지키기가 쉽지 않다. 그러나 의약품 과 달리 효능의 수준에 있어 분명한 차이가 있고 의약품으로 오인하 여 남용하는 경우 정작 필요한 치료시기를 놓치거나 잘못된 사용으 로 부작용을 겪을 수도 있다. 따라서 어떤 제품에서 어떤 성분이 어 떤 효과를 가져오는 것으로 오인할 가능성이 있는지에 대해 소비자 와 사업자, 규제기관이 협력하여 기준을 정하고 감시하는 것이 필요 하다.

\section{Author's contribution}

ISS and KK contributed equally to this work. ISS and KK designed research together. ISS collected data and analyzed data. KK reviewed literatures and wrote the manuscript. All authors read and approved the final manuscript.

\section{Author details}

In Seon Shim (Graduate student), Department of Consumer Studies, The Catholic University of Korea, 43 Jibong-ro, Bucheon-si, Gyeonggi-do 14662, Korea; Kyungja Kim (Professor), Department of Consumer Studies, The Catholic University of Korea, 43 Jibong-ro, Bucheonsi, Gyeonggi-do, 14662, Korea.

\section{References}

Choi SH, Hong RH. Investigation of consumers' knowledge and preference towards functional cosmetics. Journal of the Korean Society of Fashion \& Beauty, 3: 55-64, 2005.

Jang SH, Lee MJ, Lee KH, Do HJ, Kim JA, Kwon ES, Kim $\mathrm{MH}$, Jang JH, Kim KL. A study about satisfaction level of ordinary cosmetics and cosmeceuticals for adult women. Journal of Beauty Art Management, 6: 89-98, 2012.

Kim KJ, Han HS. Marketing strategies and consumer 
recognition of medical cosmetics. Asian Journal of Beauty and Cosmetology, 16: 569-578, 2018.

KHIDI. 2017 Report on cosmetic market. Korean Health Industry Development Institute, Chengju-si, pp41-42, 2017.

KSURE. Cosmetic industry trends and analysis of trends at home and abroad. Korea Trade Insurance Corporation, Seoul, p2, 2018.

Lee J. Consumer perception and selection attributes of anti-pollution cosmetics. Asian Journal of Beauty and Cosmetology, 16: 465-476, 2018.

Lee JG. A research of cosmeceuticals labelling and advertising activities. Korea Consumer Agency, Seoul, pp1-44, 2002.

Meng J, Pan PL. Investigating the effects of cosmeceutical product advertising in beauty-care decision making. International Journal of Pharmaceutical and Healthcare Marketing, 6: 250-266, 2012.

Park JH, Song YS, Lee KK. A study on purchasing behavior, usage and satisfaction of medical skin care cosmetics. Journal of the Korean Society of Beauty Cultural Arts, 3: 23-37, 2014.

Park SH, Kwon HJ. Customers' convergent recognition and satisfaction about cosmeceuticals. Journal of Digital Convergence, 15: 459-464, 2017.

Phaiboon-udomkarn B, Josiassen A. Attracting consumers in the thriving cosmeceuticals market: a new innovation breakthrough. Strategic Direction, 30: 38-40, 2014.

Sim EK, Kim KR. Consumer's preference and determinants of purchase of cosmeceutical products. Journal of the Korean Society of Cosmetology, 14: 1264-1279, 2008.

Song SJ, Kim YA. A study on the future market prospect of domestic functional cosmetics industry: focused on the cosmeceutical products. Journal of the Korean Society of Design Culture, 15: 258-271, 2009.

Turnbull SE. Regulating cosmeceuticals in the United States: a cosmetic industry review. ProQuest Dissertation Publishing, University of Southern California, pp151152, 2016.

You EK, Kwon HJ. Analysis of the internet shopping mall users' perception on cosmeceuticals. Journal of Digital Convergence, 14: 555-560, 2016.

Yun JJ, Kweon SA. A study of consumption practices and needs for cosmeceuticals of female university students. Korean Journal of Human Ecology, 13: 271-282, 2004. 


\section{국문초록}

\section{기능성 화장품 시장의 의약품 오인 표시·광고 사례분석}

심인선, 김경자*

가톨릭대학교 생활과학대학 소비자주거학과, 경기도 부천시, 한국

목적: 본 연구는 소비자를 오인하게 할 우려가 있어 한국 식품의약품안전처에 적발된 기능성화장품 광고를 분석하였다. 기능성화장 품에 대한 표시광고법 위반으로 적발된 141 개 광고를 분석하여 소비자 오인의 내용을 밝히고 개선방안을 논의하고자 하였다. 방법: 분석 대상 자료는 한국 식품의약품 안전처에 광고위반으로 적발된 출판광고 중 2019년 9월 현재 확인이 가능한 광고 141 개이다. 사 례연구 방식을 통해 각 광고의 내용을 기능성화장품에 대한 표시광고법과 비교해 해석하고 문제점을 해석하였다. 결과: 적발된 분 석 대상 광고 중 기초제품이 $78.9 \%$ 를 차지하여 가장 많았다. 기초제품은 문장과 이미지를 사용해 주로 트러블 케어, 피부재생, 안티 에이징, 면역력 강화 등을 주장하면서 의약품인 것처럼 소비자를 오인시키는 것이 많았다. 결론: 의약품과 기능성 화장품을 구분하 는 것은 태생적으로 쉽지 않고 따라서 기능성화장품의 광고위반을 판정하는 것도 그러하다. 그러므로 화장품 광고기준의 조항을 명 확히 하고 위반광고의 내용을 투명하게 공개하며 관련 당사자들을 교육시키는 것이 반드시 필요하다.

핵심어: 코슈메슈티컬, 코스메슈티컬 표시와 광고, 소비자 오인, 화장품 표시광고법, 소비자기만

\section{참고문헌}

김경진, 한효선. 메디컬 화장품의 마케팅 전략과 소비자 인식도. 아시안뷰티화장품학술지, 16: 569-578, 2018.

박수하, 권혜진. 코스메슈티컬 화장품에 대한 소비자들의 복합적 인식 및 만족도. 디지털융복합연구, 15: 459-464, 2017.

박지형, 송연숙, 이근광. 메디컬 스킨케어 화장품 구매행태, 사용 및 만족 정도. 대한미용문화예술학회지, 3: 23-38, 2014.

송지성, 김영아. 국내 기능성 화장품 산업의 향후 시장 전망에 관한 연구: 코스메슈디컬 제품을 중심으로. 한국디자인문화 학회지, 15: 258-271, 2009.

심은경, 김강련. 코스메슈티컬 화장품 소비자의 선호도와 구매결정요인. 한국미용학회지, $14: 1264-1279,2008$.

유은경, 권혜진. 인터넷쇼핑몰을 이용하는 소비자들의 기능성화장품에 대한 인식 실태 분석. 디지털융복합연구, $14: 555-$ 560, 2016.

윤지주, 권수애. 여대생의 기능성화장품 사용실태와 요구도. 한국생활과학회지, 13: 271-282, 2004. 이정구. 기능성 화장품의 표시·광고 실태조사. 한국소비자원, 서울, pp1-44, 2002.

이지선. 안티폴루션 화장품의 소비자인식 및 선택속성. 아시안뷰티화장품학술지, 16: 465-476, 2018.

장숙희, 이명진, 이기혜, 도희진, 김진아, 권은숙, 김미향, 장제현, 김금란. 성인여성의 기능성화장품과 일반화장품의 만족 도에 관한 연구. 미용예술경영연구, $6: 89-98,2012$.

최선혜, 홍란희. 기능성 화장품에 대한 소비자 인지도와 선호도 조사. 한국패션뷰티학회지, 3: 55-64, 2005.

한국무역보험공사. 국내외 화장품 산업동향 및 트랜드 분석. 한국무역보험공사, 서울, $\mathrm{p} 2,2018$.

한국보건산업진흥원. 2017 화장품산업 분석 보고서. 한국보건산업진흥원, 청주시, pp41-42, 2017. 


\section{中文摘要}

\section{化妆品广告中的消费者误解分析}

沈仁善, 金庚子

天主教大学生活科学大学消费者住居学科, 京畿道富川市, 韩国

目的: 本研究分析了韩国食品药品监督管理局（KFDA）披露的化妆品广告中的消费者误解。在审查了141条违反 化妆品不当标示和广告规定的广告后, 讨论了消费者误解的关键因素和管理方案。方法: 数据是从韩国食品药品 安全部因不当广告而受到处罚的广告中抽取的。每种情况都被解释为违反化妆品中不正当标示和广告的规定。 结果: 护肤产品在其他化妆品中占最高比例 $(78.9 \%) ，$ 这些化妆品违反法规，夸大了其护理，更新，抗衰老特 性, 增强免疫力等效果。特殊成分的美容效果被文字和图像夸大, 导致消费者误解。结论: 医疗和药妆产品与违 法判决之间的区别是模棱两可的。为了减少对消费者的误解, KFDA应该制定具体的法规条款, 并对正规化人员 进行教育。

关键词: 药妆, 药妆广告, 消费者的误解, 药妆法, 消费者欺骗 
